\title{
Kajian Hukum Hak Atas Tanah Masyarakat Long Midang Yang Memiliki Tanah Melebihi Ketentuan Dalam Undang-Undang RI Nomor 56 No.56 PRP Tahun 1960 Tentang Penetapan Luas Tanah Pertanian
}

\author{
Steven Daustina Asprila dan Abdul Mukmin \\ steveniven7@gmail.com, Abdulmukminrehas@gmail.com \\ Alumni dan Dosen Faklultas Hukum \\ Universitas Widya Gama Mahakam Samarinda
}

\begin{abstract}
ABSTRAK
Tanah merupakan sumber kehidupan bagi makhluk hidup baik manusia,hewan,atau tumbuh-tumbuhan. Manusia hidup dan tinggal diatas tanah dan memanfaatkan tanah untuk sumber kehidupan dengan menanam tumbuhtumbuhan yang menghasilkan makanan. Mengingat begitu pentingnya tanah karena dapat menghasilkan sumber daya alam yang sangat bermanfaat bagi orang banyak maka perlu diatur pemerintah. Tanah juga merupakan salah satu faktor produksi yang sangat vital bagi kehidupan manusia dan pembangunan dalam suatu bangsa. Peningkatan volume pembangunan dalam suatu negara, mengikis pentingnya tanah untuk pertanian. Pertambahan penduduk yang memerlukan areal yang luas, mengakibatkan mengecilnya atau berkurangnya persedian tanah. Kemudian pemerintah membuat Undangundang Nomor 56 PRP Tahun 1960 Tentang penetapan luas tanah pertanian, bahwa dalam asalusul kepemilikan atas tanah pertanian yang dilakukan masyarakat Long Midang adalah dengan cara turun-temurun. Dan pada saat proses pengembalian hak atas tanah masyarakat Long midang sesuai dengan batas maksimal yang dilakukan pemerintah untuk program landreform terdapat permasalahan yaitu masyarakat Long Midang tidak setuju dengan program tersebut, karena masyarakat Long Midang tidak ingin sebagian dari tanah pertaniannya di ambil oleh pemerintah. Dan pada umumnya tanah pertanian yang dikuasai masyarakat di Long Midang dipergunakan untuk lahan pertanian mengingat potensi daya alam di sini cukup berlimpah dan itupun yang dimanfaatkan oleh masyarakat di Long Midang sebagai lahan pertanian, seperti membuat sawah, perkebunan, ladang, dan masih banyak lagi yang dimanfaatkan oleh masyarakat yang ada. Tetapi masyarakat belum mengetahui adanya batas minimal dan maksimal terhadap tanah pertanian yang mereka kuasai.
\end{abstract}

Kata kunci : masyarakat tidak mengetahui adanya batas minimal dan maksimal terhadap tanah pertanian yang mereka kuasai. 


\begin{abstract}
The land is a source of life for living creature, whether human, animal or plant. Humans live and live on the ground and these the land to source life by planting plants that produce food. Considering the importance of land because it can produce natural resources that are very beneficial for many people, the government needs to be related. Landis also one of the factors of production that are vital for human life and development in a nation. An increase in the volume of development within a country, eroding the importance of land for agriculture. Population growth requires a large area, resulting in reduced or reduced land supply. Then the government made law number 56 of PRP in 1960 concerning the stipulation of the area of agricultural land carried out by the long midrange community was hereditary. And at the time of the process of returning the rights to the community's land long midrange program, there was a problem that the long midrange community did not agree with the program because the long midrange community did not want a portion it the agricultural land was taken by the government. And in general, agricultural land controlled by the people in long midrange is used for agricultural land because the potential of natural resources here is quite abundant and even then that is used by the people in long midrange as agricultural lands, such as making rice field, plantations, fields, and still many more are use our exciting community. But the community does not know of the minimum and maximum limit or agricultural land they community.
\end{abstract}

Key words: The community is not aware of the minimum and maximum limits on agricultural land control.

\section{PENDAHULUAN}

\section{A. Latar Belakang}

Tanah merupakan sumber kehidupan bagi makhluk hidup baik manusia, hewan, atau tumbuh-tumbuhan. Manusia hidup dan tinggal diatas tanah dan memanfaatkan tanah untuk sumber kehidupan dengan menanam tumbuh tumbuhan yang menghasilkan makanan. Mengingat begitu pentingnya tanah karena dapat menghasilkan sumber daya alam yang sangat bermanfaat bagi orang banyak maka perlu diatur pemerintah. Tanah juga merupakan salah satu faktor produksi yang sangat vital bagi kehidupan manusia dan pembangunan dalam suatu bangsa. Peningkatan volume pembangunan dalam suatu negara, mengikis pentingnya tanah untuk pertanian. Pertambahan penduduk yang memerlukan area yang luas, mengakibatkan mengecilnya atau berkurangnya persedian tanah. Tanah merupakan sumber daya yang penting bagi masyarakat, khususnya petani. Petani yang memerlukan tanah pertanian sebagai tanah mempertinggi produksi pertanian dan upaya bertahan hidup, tanah pertanian sangat penting nilainya dalam suatu bangsa, karna sebagai salah satu penopang ketahanan pangan dalam suatu negara. Karna pentingnya tanah pertanian, maka tanah pertanian perlu diatur keberadaannya agar tidak dikuasai secara besar-besaran oleh sebagian pihak saja.

Tanah pertanian berhubunganerat denganLandreform. Landreform merupakan pengaturan mengenai pemilikan tanah pertanian dengan manusia. Program landreform di Indonesia meliputi :

1) Pembatasan luas maksimum pengusaan tanah.

2) Larangan pemilikan tanah secara 
absentee/guntai.

3) Redistribusi tanah-tanah yang selebihnya dari batas maksimum, tanahtanah yang terkena larangan absentee/guntai, tanah-tanah bekas swapraja dan tanah-tanah Negara .

4) Pengaturan soal pengembalian dan penebusan tanah-tanah pertanian yang digadaikan.

5) Pengaturan kembalian perjanjian bagi hasil tanah pertanian.

6) Penetapan luas minimum pemilikan tanah pertanian, disertai larangan untuk melakukan perbuatan-perbuatan yang mengakibatkan pemecahan pemilikan tanah-tanah pertanian menjadi bagian yang terlampau kecil.

Undang-Undang Dasar Tahun 1945 pasal 33 ayat 3 berbunyi sebagai berikut: Bumi, air dan kekayaan alam yang terkandung didalam dikuasi oleh negara dan dipergunakan untuk sebesar-besarnya kemakmuran rakyat. Untuk merealisasi pasal 33 ayat (3) Undang-Undang Dasar 1945 maka ditetapkan Undang-Undang Nomor 5 Tahun 1960 Tentang Peraturan Dasar Pokok Agraria yang juga disebut dengan singkatan UUPA. Dalam UndangUndang Nomor 5 Tahun 1960 Tentang Peraturan Dasar Pokok Agraria pasal 16 mengatur tentang hak-hak atas tanah sebagai yang dimaksud dalam pasal 4 ayat (1) ialah :

\section{Hak milik}

Hak milik adalah hak turun-temurun terkuat dan terpenuhi yang dapat dipunyai orang atas tanah dengan mengingat ketentuan dalam pasal 6 .

\section{Hak guna usaha}

Hak guna usaha adalah hak untuk menggunakan tanah yang dikuasai langsung oleh Negara. Dalam jangka waktu sebagaimana tersebut dalam pasal 29 , guna perusahaaan pertanian, perikanan atau perternakan. Hak guna usaha diberikan atas tanah yang luasnya paling sedikit 5 hektar dengan ketentuan bahwa jika luasnya 25 hektar atau lebih harus memakai investasi modal yang layak dan teknik perusahaan yang baik yang sesuai dengan perkembangan zaman.

\section{Hak guna bangunan}

Hak guna bangunan adalah hak untuk mendirikan atau mempunyai bangunanbangunan atas tanah yang bukan miliknya sendiri. dengan waktu yang paling lama 30 tahun. Atas permintaan pemegang hak dan dengan mengingat keperluan serta keadaan bangunan-bangunannya. Jangka waktu tersebut dalam ayat 1 dapat diperpanjang dengan waktu paling lama 20 tahun.

\section{Hak pakai}

Hak pakai adalah hak untuk menggunakan dan/atau memungut hasil dari tanah yang dkuasai langsung oleh Negara atau tanah milik orang lain. Yang memberi wewenang dan kewajiban yang ditentukan dalam keputusan pemberiannya oleh pejabat yang yang berwenang memberikannya atau perjanjian dengan pemilik tanahnya. Yang bukan perjanjian sewamenyewa atau perjanjian pengolahan tanah, segala sesuatu asal tidak bertentangan dengan jiwa dan ketentuan undang-undang ini.

\section{Hak sewa}

Hak sewa untuk bangunan seseorang atau badan hukum mempunyai hak sewa atas tanah, apabila ia berhak mempergunakan tanah milik orang lain untuk keperluan bangunan, dengan membayar kepada pemiliknya sejumlah uang sebagai sewa. 


\section{Hak membuka tanah}

Hak membuka tanah dan memungut hasil hutan hak membuka tanah dan pemugut hasil hutan hanya dapat dipunyai warga negara Indonesia dan diatur dengan peraturan pemerintah.

\section{Hak memungut hasil hutan}

Hak guna air, pemeliharaan dan penangkapan ikan hak guna air ialah hak memperoleh air untuk keperluan tertentu dan/atau mengalirkan air itu atas tanah orang lain. Hak guna serta pemeliharaan dan penagkapan ikan diatur dengan peraturan pemerintah.

\section{Hak-hak lain yang tidak termasuk dalam hak-hak yang sifatnya sementara sebagai yang disebutkan dalam pasal 53;}

Hak guna ruang angkasa memberi wewenang untuk mempergunakan tenaga dan unsur-unsur dalam ruang angkasa guna usaha - usaha memelihara dan memperkembangkan kesuburan bumi, air serta kekayaan alam yang terkandung didalamnya dan hal-hal lainnya yang besangkutan dengan itu.

Menurut Ismaya Samun dalam bukunya yang berjudul pengantar hukum agraria berdirinya cabang ilmu hukum agraria kiranya menjadi sebuah tuntutan atau keharusan, karena :

a. Persoalan agraria mempunyai arti penting bagi bangsa dan negara agraris.

b. Dengan adanya

kesatuan/kebulatan, akan memudahkan bagi semua pihak untuk mempelajarinya.

c. Di samping masalah agraria yang mempunyai sifat religus, masalah tanah adalah soal masyarakat bukan persoalan perseorangan. ${ }^{1}$

1 Ismaya Samun, 2011, Pengantar Hukum Agraria, Penerbit Graha Ilmu, Yogyakarta, Hal.9
Undang- Undang No.56 PRP Tahun 1960 Tentang Penetapan Luas Tanah Pertanian dalam pasal 1 ayat (2) dengan memperhatikan jumlah penduduk, daerah dan faktor-faktor lainnya, maka luas maksimum yang dimaksud dalam ayat (1) pasal ini ditetapkan di daerah-daerah yang tidak padat (15 hektar) dan padat (12 hektar) pengusaan terhadap tanah.

Penelitian ini melakukan kajian terhadap luasan tanah pertanian yang dikuasi melebihi ketentuan yang berlaku. Bahwa dalam asal-usul kepemilikan atas tanah pertanian ini berawal dari pembukaan lahan, yang dilakukan masyarakat Long Midang secara turuntemurun. Dan pada saat proses pengembalian hak atas tanah masyarakat Long midang sesuai dengan batas maksimal yang dilakukan pemerintah untuk program landreform terdapat permasalahan yaitu masyarakat Long Midang tidak setuju dengan program tersebut, karena masyarakat Long Midang tidak ingin sebagian dari tanah pertaniannya di ambil oleh pemerintah. Sehingga menurut penulis saat ini penguasaan tanah pertanian yang ada di Long Midang dapat dikategorikan sebagai kesalahan dalam penguasaan terhadap tanah pertanian, yang diatur dalam Undang-Undang Nomor 56 PRP Tahun 1960 Tentang Penetapan Luas Tanah Pertanian Pasal 1 ayat (2) bahwa dalam penjelasannya batas penguasaan terhadap tanah hanya (12 hektar). Sehingga dalam proses pengembalian batas hak atas tanah masyarakat Long Midang mengalami kendala dan terhadap tanah pertanian mereka haknya tidak dapat di sahkan secara hukum.

\section{B. Permasalahan}

Adapun permasalahan dalam penelitian ini sebagai berikut :

1. Apakah yang menyebabkan kepemilikan hak atas tanah masyarakat Long Midang melampaui batas (melebihi ketentuan dalam Undang-Undang Nomor 56 PRP Tahun 1960 Tentang penetapan luas tanah pertanian)? 
2. Bagaimana upaya pemerintah dalam pengembalian hak atas tanah masyarakat Long midang sesuai dengan batas maksimal sesuai dengan Undang-Undang Nomor 56 PRP Tahun 1960 Tentang penetapan luas tanah pertanian?

\section{Tujuan dan Manfaat Penelitian}

Adapun Tujuan penelitian ini adalah untuk mengetahui penyebab tanah pertanian masyarakat Long Midang yang memiliki tanah diatas ketentuan yang berlaku, dan untuk mengetahui upaya pemerintah dalam pengembalian hak atas tanah masyarakat Long midang sesuai dengan batas maksimal.

Adapun penelitian ini bermanfaat tidak hanya secara teoritis melainkan juga secara praktis yaitu untuk memberikan sumbangsi pemikiran dalam rangka input bagi aparatur Negara.

\section{METODE PENELITIAN}

Jenis penelitian yang digunakan dalam penelitian ini adalah Penelitian Yuridis Empiris, sehingga sumber data yang digunakan dalam penelitian ini, Pertama Populasi atau masyarakat Long Midang yang memiliki tanah pertanian sesuai ketentuan yang berlaku, dan Kedua adalah Sampel yaitu responden 10\% (Sepuluh persen) dari masyarakat Long Midang yang memiliki tanah sesuai ketentuan yang berlaku.

Penelitian ini berlokasi di daerah Kabupaten Nunukan, tepatnya pada Lokasi Long Midang Kecamatan Krayan induk, Kabupaten Nunukan Provinsi KALTARA (KALIMANTAN UTARA).

Adapun penelititi memperoleh Data yang digunakan dengan cara Metode observasi yaitu pengamatan langsung terhadap objek yang diteliti dan Metode wawancara yaitu dalam hal ini peneliti melakukan wawancara dengan pihak yang dapat memberikan informasi yang berhubungan dengan permasalahan yakni kantor pemerintah daerah yang ada di Kabupaten Nunukan, dan perangkat desa masyarakat Long Midang baik ditingkat kelurahan maupun di kecamatan, serta masyarakat di Long Midang selaku pemilik tanah pertanian.

Teknik Pengumpulan Data dalam penelitian ini adalah dengan cara mengumpulkan data dari eksplorasi, hal ini digunakan untuk memperoleh pemahaman tentang alasan yang mendasari, opini, dan motivasi. Metode pengumpulan data kualitatif cukup bervariasi, bisa menggunakan teknik terstruktur dan semi terstruktur.

Metode analisis data yang sesuai dengan penelitian ini adalah dengan menggunakan pendekatan secara kualitatif, yang dimaksudkan untuk mengambarkan fenomena - fenomena yang terjadi dilapangan terutama yang berkaitan dengan masalah yang diteliti. Untuk keperluan tersebut peneliti menyederhanakan data yang diperoleh kedalam bentuk yang mudah dibaca, dipahami, dan di interpretasi yang pada hakekatnya merupakan upaya penelitian untuk mencari jawaban atas permasalahan yang dirumuskan. Dalam penelitian ini peneliti berusaha menggambarkan kajian hukum hak atas tanah masyarakat Long Midang yang memiliki tanah melebihi ketentuan dalam Undang-Undang Nomor. 56 PRP Tahun 1960 Tentang Penetapan Luas Tanah Pertanian.

\section{HASIL DAN PEMBAHASAN}

\section{A. Penyebab kepemilikan hak atas tanah masyarakat Long Midang melampaui batas (melebihi ketentuan dalam Undang-Undang Nomor 56 PRP Tahun 1960 Tentang Penetapan Luas Tanah Pertanian).}

Kepemilikan tanah pertanian masyarakat Long Midang berdasar pada hasil penelitian yang dilakukan banyaknya masyarakat yang menguasai tanah pertanian melebihi batas maksimal yang telah ditetapkan oleh pemerintah. Namun demikian penguasaan hak atas tanah pertanian yang melampaui batas pada dasarnya tidak menimbulkan konflik dalam tataran kehidupan masyarakat Long Midang, hal ini dibuktikan dengan tidak adanya masyarakat yang bersengketa hak 
atas tanah pertanian karena batas yang luas, tetapi sengketa tanah yang umum ada di kehidupan masyarakat adalah terkait hibah, jual beli dan sengketa batas. Bagi masyarakat Long Midang, menguasai hak atas tanah pertanian diatas $20 \mathrm{Ha}$ adalah merupakan hal biasa, ini disebabkan karena umumnya pekerjaan atau mata pencarian utama masyarakat Long Midang adalah berkebun dan bertani.

Layaknya yang dapat diketahui dari masyarakat Long Midang, bahwa hampir semua tanah yang dikuasai oleh masyarakat bersumber dari warisan adat atau dalam hukum perdata disebut dengan hak waris, yang mana hal ini pula yang akan menjadi bagian tradisi atau budaya masyarakat Long Midang saat ini yang akan diteruskan oleh generasi selanjutnya di masyarakat Long Midang.

Ketika berbicara aturan tentang pertanahan maka apa yang ada di Desa Long Midang saat ini adalah salah satu khususnya dalam hal luasan tanah yang dikuasai oleh masyarakat, dimana dalam aturan jelas luasan maksimal yang dapat dikuasai oleh setiap orang adalah maksimal $20 \mathrm{Ha}$, namun demikian ketika hal tersebut dikaitkan dengan budaya atau adat masyarakat Long Midang maka hal ini tentu membutuhkan penjelasan terkait mengapa mereka bisa menguasai tanah pertanian dengan luasan melebihi ketentuan yang ada. Dalam pembahasan ini, peneliti juga akan mencoba memaparkan factor factor yang menyebabkan masyarakat Long Midang kemudian menguasai hak atas tanah pertanian melebihi 20 Ha bahkan ada yang sampai 50 Ha perorang.

\section{Kepemilikan tanah masyarakat Long Midang yang bersifat turun- temurun (warisan). \\ Sistem kepemilikan tanah} masyarakat Long Midang adalah turuntemurun, dimana hampir semua tanah yang dikuasai oleh masyarakat Long Midang saat ini adalah merupakan warisan yang bersifat turun-temurun dari generasi sebelumnya, sehingga banyak sekali masyarakat Long Midang saat ini yang memiliki melebihi 20 Ha. Yang berarti ke generasi berikutnya dapat menguasai tanah pertanian dengan jumlah yang sama. Sebagaimana diketahui kepemilikan hak atas tanah pertanian yang dikuasai maksimal $20 \mathrm{Ha}$ untuk wilayah yang tidak padat, sesuai dengan undangundang nomor 56 PRP tahun 1960 tentang penetapan luas tanah pertanian.

\section{Budaya bertani dan berkebun dengan cara berpindah-pindah. \\ Budaya masyarakat yang berpindah-} pindah, karena masyarakat yang memiliki tanah pertanian pada umumnya tidak menentu dalam hal kepemilikannya. Apabila lahan pertanian yang mereka kuasai tidak mendapatkan hasil yang maksimal, masyarakat Long Midang biasanya membuka lahan yang baru lagi dengan maksud dan harapan untuk mendapatkan hasil yang maksimal dari lahan pertanian sebelumnya.

\section{Adanya kewenangan pengelolaan tanah adat dari pemerintah.}

Kewenangan pengelolaan tanah pertanian adat oleh pemerintah, pemerintah daerah memberikan hak kewenangan pengelolaan tanah pertanian kepada adat untuk dapat mengatur distribusi tanah pertanian kepada masyarakat Long Midang. Sehingga kepemilikan tanah pertanian masyarakat Long Midang jika dilihat dari jumlah serta luasan yang diberikan sangat berbeda dari ketentuan, sehingga penguasaannya melebihi aturan yang ada.

\section{Sifat masa bodoh}

Sifat masa bodoh masyarakat Long Midang yang belum mengetahui adanya batas minimal dan maksimal terhadap tanah pertanian yang mereka kuasai, sehingga banyak tanah pertanian yang dikuasai secara berlebihan dan pihak desa juga jarang terlibat dalam hal sosialiasi terhadap urusan tanah pertanian.

\section{Lemahnya sosialisasi}

Ketidaktahuan masyarakat dalam hal sosialisasi, lemahnya kesadaran masyarakat Long Midang dalam hal mengikuti sosialisasi dari pemerintah daerah tentang program pengaturan tanah pertanian yang berlaku sesuai dengan aturan dan ketentuan yang ada, sehingga masih banyak dari 
masyarakat Long Midang yang tidak mengerti atau bahkan tidak memahami adanya pengaturan terhadap tanah pertanian yang mereka kuasai secara pribadi.

\section{Lemahnya penerapan sanksi}

Lemahnya penerapan sanksi hukum, penerapan sanksi langsung maupun teguran belum ada yang di berikan kepada masyarakat Long Midang secara langsung atau nyata. Karena penguasaan tanah pertanian perorangan di Kecamatan Krayan Induk khususnya di Long Midang belum ada kontrol yang secara berkala, dikarenakan akses menuju ketempat lokasi sangat sulit dan hanya bisa di tempuh dengan berjalanan kaki serta letak-letak tanah pertanian masyarakat Long Midang jauh dari daerah pemukiman dan tidak didukung dengan data penunjang seperti bukti surat kepemilikan hak atas tanah yang dimiliki, batas-batas tanah yang tidak sesuai, dan ketidak pastian siapa pemilik aslinya, sehingga itulah yang masih menjadi kendala utama bagi pemerintah yang ada di Kabupaten Nunukan untuk memberikan sanksi- sanksi kepada masyarakat yang memiliki tanah pertanian melebihi ketentuan yang berlaku.

Pada umumnya hal-hal yang menyebabkan terjadinya penguasaan tanah pertanian dari masyarakat Long Midang melebihi ketentuan yang ada, karena kurangnya kesadaran dari masyarakat terhadap pentingnya memiliki tanah pertanian dengan ketentuan yang sudah diatur dalam undang-undang nomor 56 PRP tahun 1960 tentang penetapan luas tanah pertanian. Kemudian dalam ketentuan pasal 7 Undang-Undang Nomor 5 Tahun 1960 Tentang Pokok-Pokok Agraria kemudian ditegaskan kembali dalam pasal 17 Undang- Undang Nomor 5 Tahun 1960 Tentang Pokok-Pokok Agraria yang mengamanatkan pengaturan luas maksimum dan/atau minimum tanah yang boleh dipunyai dengan suatu hak atas tanah oleh satu keluarga atau badan hukum. Penetapan luas maksimum tersebut tidak ditentukan dalam Undang-Undang Nomor 5 Tahun 1960 Tentang Pokok-Pokok Agraria, melainkan diatur dalam suatu peraturan perundang-undangan tersendiri. Tanah yang melampaui batas maksimum tidak akan disita, namun akan diambil oleh pemerintah dengan ganti kerugian, untuk selanjutnya dibagikan kepada rakyat yang membutuhkan. Pada prinsipnya ganti kerugian tersebut dibayar oleh mereka yang memperoleh bagian tanah itu, namun karena umumnya yang memperoleh pembagian tanah berasal dari golongan yang tidak mampu, maka pemerintah akan menyalurkan dengan cara kredit atau melaui upaya-upaya lain agar para bekas pemilik tanah tidak terlalu lama menunggu uang ganti kerugian.

Pemerintah pada tanggal 29 desember 1960 melaksanakan apa yang telah diamanatkan dalam pasal 17 UndangUndang Nomor 5 Tahun 1960 Tentang Pokok- Pokok Agraria tersebut, dengan menetapkan Peraturan Pemerintah Pengganti Undang- Undang Nomor.56 Tahun 1960 Tentang Penetapan Luas Tanah Pertanian, yang kemudian ditetapkan menjadi undang-undang (selanjutnya disebut Undang-Undang Nomor 56 PRP 1960). Luas maksimum tanah pertanian yang ditentukan dalam Undang- Undang Nomor 56 PRP 1960 Tentang Penetapan Luas Tanah Pertanian adalah sebagai berikut :

a. Daerah-daerah yang tidak padat (kepadatan penduduk sampai 50 tiap kilometer persegi), luas maksimum penguasaan tanah pertanian adalah 15 hektar untuk sawah atau 20 hektar untuk tanah kering.

b. Daerah-daerah yang kurang padat (kepadatan penduduk 51 sampai 250 tiap kilometer persegi). Luas maksimum pengusaan tanah pertanian adalah 10 hektar untuk sawah atau 12 hektar untuk tanah kering.

c. Daerah-daerah yang cukup padat (kepadatan penduduk 251 sampai 400 tiap kilometer persegi). Luas tanah maksimum pengusaan tanah pertanian adalah 7,5 hektar untuk sawah atau 9 hektar untuk tanah kering.

d. Daerah-daerah yang sangat padat (kepadatan penduduk 401 ke atas), luas maksimum penguasaan tanah pertanian 
adalah 5 hektar untuk sawah atau 6 hektar untuk tanah kering.

Untuk lebih menjelaskan mengenai pasal 1 ayat (2) Undang-Undang PRP 56 Tahun 1960, maka perlu dilihat ketentuan dalam penjelasannya dari pasal 1 ayat (2) yang dimaksud, misalnya di daerah yang kurang padat oleh suatu keluarga di kuasai 5 ha sawah dan 9 ha tanah kering. Maka 5 ha sawah dihitung menjadi tanah kering, yaitu $120 \% \times 5$ ha $=6$ ha. Jadi, yang dikuasai jumlahnya sama dengan $6+9$ ha= 15 ha tanah kering. Karena untuk daerah yang kurang padat maksimumnya 12 ha tanah kering. Maka keluarga itu harus melepaskan 15-12 ha = 3 ha tanah kering. Dengan demikian maka maksimumnya ialah 5 ha sawah dan 6 ha tanah kering atau 11 ha. Jika sawah yang akan dilepaskan maka 9 ha tanah kering itu dihitung menjadi sawah, yaitu sama dengan sawah $5 / 6 \times 9$ ha $=7,5$ ha. Dengan demikian, jumlah tanahnya adalah 5 ha $+7,5$ ha $=12,5$ ha sawah. Karena untuk daerah tersebut maksimumnya 10 ha, maka sawah yang harus dilepaskan adalah 12,5 ha-10 ha. Bagi keluarga itu maksimumnya menjadi 2,5 ha sawah dan 9 ha tanah kering atau 11,5 ha. Perlu diperhatikan bahwa bagaimanapun jumlah luas tanah sawah dan tanah kering itu tidak boleh lebih dari 20 ha, baik di daerah yang padat maupun tidak padat. Maka peran serta dari masyarakat yang memiliki tanah pertanian melebihi ketentuan yang berlaku, haruslah saling membantu dari program pemerintah dalam hal pengaturan untuk tanah pertanian agar dalam kepemilikan atas tanah pertaniannya dapat diakui kepemilikannya secara hukum. Serta memberikan kesejahteraan dan kesetaraan dalam hal penguasaan terhadap tanah pertanian diatas ketentuan yang berlaku.

\section{B. Upaya pemerintah dalam pengembalian hak atas tanah masyarakat Long Midang sesuai dengan batas maksimal sesuai dengan Undang-Undang Undang Nomor 56 PRP Tahun 1960 Tentang Penetapan Luas Tanah Pertanian.}

Upaya yang dilakukan oleh pemerintah dalam rangka pengembalian hak atas tanah masyarakat Long Midang sesuai dengan batas maksimal sesuai dengan undang- undang nomor 56 PRP tahun 1960 tentang penetapan luas tanah pertanian adalah sebagai berikut:

\section{Sosialisasi}

Pemerintah dalam hal ini untuk usaha pengembalian hak atas tanah masyarakat Long Midang sesuai dengan batas maksimal dengan undang-undang nomor 56 PRP tahun 1960 tentang penetapan luas tanah pertanian, mengadakan sosialisasi mengenai batas penguasaan atas tanah pertanian yang dikuasai oleh masyarakat Long Midang sesuai dengan ketentuan yang berlaku. Dan sosialisasi ini diselenggarakan di kantor Desa Buduk Kinangan dalam pertemuan ini di hadiri oleh pengurus adat Desa Long Midang, Kepala Desa yang ada, Perangkat Desa, serta masyarakat Long Midang yang akan menjadi objek penerima dari manfaat dari program dimaksud. Hadir dari perwakilan tersebut dari pemerintah yang memberikan sosialisasi untuk warga masyarakat di Long Midang, Kecamatan Krayan Induk, Kabupaten Nunukan.

Peran dari pemerintah dalam melaksanakan program pengembalian batas tanah warga masyarakat Long Midang yang memiliki tanah pertanian melampaui ketentuan yang ada sudah maksimal, dan memberi solusi atas tanah pertanian masyarakat yang belum memiliki kejelasan atau kepastian hukum, sehingga terhadap tanah-tanah pertanian masyarakat yang melampaui batas maksimal dari ketentuan yang sudah di atur dalam undang-undang nomor 56 PRP tahun 1960 tentang penetapan luas tanah pertanian. Serta dapat memiliki kepastian hukum dan rasa aman terhadap tanah pertanian yang mereka kuasai dengan keberadaannya diakui oleh negara, agar terciptanya kesejahteraan dan kesetaraan dalam hal penguasaan hak atas tanah pertanian sesuai dengan aturan yang ada khususnya di Long Midang.

Adapun yang menjadi tujuan dari pemerintah menjalankan sosialisasi ini adalah untuk memberikan pemahaman kepada masyarakat Long Midang, untuk 
dapat memahami mekanisme program dari pemerintah tentang penguasaan hak atas tanah pertanian masyarakat Long Midang yang memiliki tanah pertanian melebihi ketentuan yang berlaku.

Selain itu sosialisasi ini dilaksanakan agar tanah-tanah pertanian masyarakat Long Midang yang ada dapat memiliki kekuatan hukum dalam kepemilikannya, serta kepastian hukum terhadap tanah pertanian yang dimiliki oleh warga masyarakat Long Midang, dan warga yang memiliki tanah pertanian melebihi ketentuan maksimalnya dapat menguasai sesuai dengan aturan yang berlaku agar terciptanya tertib pertanahan di bidang pertanian. Untuk itu pemerintah menginginkan agar seluruh warga masyarakat di Long Midang terlebih lagi yang akan mengikuti pelaksanaan dari undang-undang nomor 56 PRP tahun 1960 tentang penetapan luas tanah pertanian dapat bekerjasama dengan baik dengan pemerintah dari awal sampai kegiatan ini sampai dengan berakhirnya kegiatan ini, pada tahapan pengukuran untuk mengetahui pengembalian batas tanah pertanian sesuai dengan ketentuan yang berlaku, pemerintah menghimbau kepada masyarakat Long Midang untuk dapat hadir langsung di lapangan agar saat dilakukannya pengukuran tidak terjadinya sengketa atau masalah atas tanah pertanian yang akan dilakukan tindakan pengukuran, dan pemilik serta tetangga yang berbatasan langsung lahannya harus bisa hadir menyaksikan serta menyetujui hasil akhir dari pengukuran, sehingga tidak terjadinya konflik yang bisa menyebabkan permasalahan terhadap tanah pertanian yang dikuasai oleh warga masyarakat Long Midang.

Diharapkan dari pelaksanaan undang-undang nomor 56 PRP tahun 1960 tentang penetapan luas tanah pertanian ini selain untuk menjamin kepastian hukum, juga diharapkan mampu membuka terjadinya pemerataan penguasaan tanah pertanian di Long Midang. Pemerintah mengharapkan sosialisasi dari program pengembalian batas hak atas tanah pertanian yang ada ini dapat terlaksana dengan baik, dan pelaksanaan ini hanya diperuntukan bagi bidang-bidang tanah pertanian yang melebihi batas kepemilikannya.

\section{Pelaksanaan program pengembalian hak atas tanah masyarakat Long Midang yang memiliki tanah melebihi ketentuan. \\ Pelaksanaan dari program} pengembalian batas tanah pertanian di Long Midang yang memiliki tanah melebihi ketentuan yang berlaku, dan program ini dilaksanakan untuk pertama kalinya dilakukan oleh pemerintah, untuk warga masyarakat di Long Midang dan dilakukan secara serentak yang meliputi semua obyek tanah pertanian yang belum didaftarkan. Pelaksanaan ini dilakukan untuk kegiatan memaksimalkan lahan pertanian yang belum di daftarkan, dan juga pendataan seluruh obyek tanah pertanian yang sudah diajukan ke pemerintah untuk guna meghimpun dan menyediakan informasi lengkap mengenai bidang-bidang tanah pertanian khususnya di Long Midang. Salah satu tahapan dari kegiatan ini adalah pengumpulan data fisik, pengumpulan data fisik meliputi:

a) Penetapan batas bidang tanah;

b) Pengukuran batas bidang tanah;

c) Pengumuman data fisik;

d) Menjalankan prosedur dan memasukan data serta informasi yang berkaitan dengan data fisik bidang pertanian di aplikasi komputerisasi kantor pertanahan (KKP). Dengan berpedoman kepada ketentuan peraturan perundangundangan yang mengatur tentang pengukuran dan pemetaan bidang tanah pertanian pengumpulan Pelaksanaan dari program pengembalian batas tanah pertanian di Long Midang yang memiliki tanah melebihi ketentuan yang berlaku, dan program ini dilaksanakan untuk pertama kalinya dilakukan oleh pemerintah, untuk warga masyarakat di Long Midang dan dilakukan secara serentak yang meliputi data fisik dalam rangka percerpatan program pengembalian batas tanah pertanian 
akan optimal hasilnya apabila dalam pelaksanaan pengukuran dan pemetaan bidang tanah pertanian dilaksanakan dengan aman sesuai prosedur yang ada serta mengelompok dalam satu wilayah desa/kelurahan lengkap, disamping harus di dukung dengan adanya ketersedian peta dasar tanah pertanian yang akan dilaksankan program pengembalian batas atas hak tanah pertanian masyarakat Long Midang.

Tujuan dari pelaksanaan pengukuran dan pemetaan bidang pertanian harus lengkap dengan mengelompokkan dalam satu wilayah desa/kelurahan lengkap diantaranya:

1. Waktu pelaksanaan relatif lebih cepat kerja petugas ukur lebih mudah dilaksanakan;

2. Dapat sekaligus diketahui bidang-bidang tanah pertanian yang belum terdaftar dan yang sudah terdaftar dalam satu wilayah desa/kelurahan;

3. Dapat sekaligus diketahui bidang-bidang tanah yang bermasalah dalam satu wilayah desa/kelurahan;

4. Persetujuan batas sebelah menyebelah lebih mudah dilaksanakan;

5. Dapat memperbaiki/melengkapi peta dasar pendaftaran.

Ruang lingkup pekerjaan pelaksanaan pendaftaran tanah pertanian di Long Midang, ruang lingkup pengukuran dan pemetaan bidang tanah pertanian adalah:

a) Ketersediaan peta dasar pendaftaran tanah pertanian;

b) Metode pelaksanaan pengukuran dan pemetaan bidang tanah pertanian;

c) Petugas pelaksana pengukuran dan pemetaan bidang tanah pertanian;

d) Proses pengukuran bidang tanah dan pengumpulan informasi bidang tanah pertanian;

e) Pelaksanaan pemetaan bidang tanah pertanian;

f) Data yang selalu tersimpan di dalam aplikasi komputerisasi kegiatan pertanahan (KKP);

g) Pengumuman;

h) Kendali mutu kegiatan pengukuran dan pemetaan bidang tanah pertanian i) Pelaporan.

Sumber pembiayaan pelaksanaan ini, dari tanah pertanian di Long Midang, kegiatan pengukuran dan pemetaan bidang tanah pertanian dibiayai dengan Anggaran Pendapatan dan Belanja Negara (APBN), Anggaran Pendapatan dan Belanja Daerah (APBD), Dana desa, Swadaya masyarakat, Swasta melalui program tanggung jawab sosial perusahaan, Dana lainnya sesuai dengan ketentuan peraturan yang berlaku.

\section{Kerjasama perangkat desa di Long Midang dengan pemerintah. \\ Lokasi Long Midang, Kecamatan} Krayan Induk, bekerjasama dengan pemerintah daerah di Kabupaten Nunukan dalam hal program upaya pemerintah melaksanakan pengembalian batas hak atas tanah pertanian masyarakat Long Midang yang memiliki tanah pertanian melampaui batas maksimal sesuai dalam ketentuan yang berlaku, kerjasama yang dilakukan oleh kedua belah pihak ini adalah pemerintah daerah memberikan kewenangan kepada perangkat adat dan desa untuk dapat mendata tanah- tanah pertanian masyarakat Long Midang yang memiliki tanah pertanian melebihi batas maksimal dari penguasaan tanah pertanian yang ada di lokasi Long Midang dan maksud pemerintah mendata tanah pertanian masyarakat Long Midang adalah untuk memberikan infomasi mengenai standar penguasaan terhadap tanah pertanian yang dikuasai oleh masyarakat yang belum mengetahui adanya batasan maksimal dari penguasaan tanah pertanian, sesuai dengan undang-undang nomor 56 PRP tahun 1960 tentang penetapan luas tanah pertanian, dalam membantu pengawasan program tersebut mengenai tanah pertanian bagi kepala keluarga di lokasi Long Midang, dan kegiatan dari program pengembalian batas tanah pertanian sesuai ketentuan yang berlaku ini dilakukan pada tahun 2017.

Kerjasama perangkat desa di Long Midang dengan pemerintah ini dalam 
pengawasan dari proses pengembalian batas tanah pertanian masyarakat dengan ketentuan yang berlaku, dan hal ini dilakukan karena masih terkendala dengan akses jalanan maupun transportasi yang masih kurang tersedia di lapangan, dan pengawasan dari pemerintah terhadap program pelaksanaan atas hak tanah pertanian di Long Midang tidak berjalan sebagaimana mestinya, sehingga pemerintah meminta bantuan kepada perangkat desa di Long Midang untuk melakukan pengawasan sementara dalam proses tersebut, karena jumlah petugas dari pihak perwakilan pemerintah yang berada di Long Midang terbatas jumlahnya.

Sehingga perangkat desa turut serta dalam membantu kegiatan tersebut, yakni mengenai tanah pertanian yang dimiliki melebihi ketentuan yang berlaku. Agar saat dilakukannya kegiatan pengembalian batas hak atas tanah pertanian yang sesuai dengan aturan yang ada, tidak terkendala dengan masalah dalam tahapan program tersebut, karena perangkat desa yang diberikan tugas ini juga mengetahui dan mengenal kondisi maupun para pemilik tanah pertanian.

Dalam proses kerjasama anatara pihak pemerintah dengan perangkat desa di Long Midang sudah dapat berjalan dengan baik dan lancar, akan tetapi hanya tanah pertanian masyarakat yang tinggal pergi oleh pemiliknya keluar desa/daerah saja yang belum sempat di lakukan prosesnya, hal tersebut disebabkan oleh terbatasnya keterbukaan dan pemahaman masyarakat dengan kegiatan ini sehingga prosesnya mengalami hambatan.

Tujuan dari pemerintah dan perangkat desa melakukan kerjasama ini ialah agar tanah-tanah pertanian yang belum dilakukan proses pengembalian hak atas tanah pertaniannya sesuai dengan ketentuan yang berlaku dapat terpenuhi dalam terselenggaranya program pelaksanaan tersebut, serta hak atas tanah pertanian yang akan dilaksanakan proses pengembalian batasnya dapat berjalan sesuai dengan aturan yang berlaku di lokasi Long Midang. Hasil dari pemerintah dalam melaksanakan program pengembalian hak atas tanah pertanian melebihi ketentuan yang dimiliki oleh masyarakat Long
Midang dengan cara melakukan kerjasama dengan pihak perangkat desa sudah maksimal, dan sesuai dengan prosesnya.

Serta harapan dari masyarakat Long Midang yang ingin melaksanakan program pengembalian hak atas tanah pertaniannya sesuai dengan ketentuan yang berlaku, dengan aturan yang ada dapat terlaksana sebagaimana mestinya. Sehingga masyarakat Long Midang sangat berterima kasih kepada pemerintah, yang sudah melaksanakan kegiatan pengembalian hak atas tanah pertaniannya sesuai dengan ketentuan yang berlaku.

Harapan dari pemerintah kepada masyarakat Long Midang khususnya yang memiliki hak atas tanah pertanian melebihi batas yang ada agar dapat memberikan data dan informasi secepatnya kepada pengurus adat atau perangkat desa apabila menguasai tanah pertanian yang melebihi ketentuan, dan aturan yang ada dapat terlaksana serta berjalan sebagaimana mestinya demi terciptanya tertib pertanahan khususnya di bidang pertanian.

\section{PENUTUP KESIMPULAN DAN SARAN}

Berdasar pada hasil pembahasan diatas, ditarik kesimpulan dalam penelitian ini bahwasannya Penyebab terjadinya penguasaan hak atas tanah dari masyarakat Long Midang melebihi ketentuan yang ada, karena kepemilikan tanah masyarakat Long Midang yang bersifat turun-temurun (warisan), budaya bertani dan berkebun dengan cara berpindah-pindah, adanya kewenangan pengelolaan tanah adat dari pemerintah, sifat masa bodoh, lemahnya sosialisasi, lemahnya penerapan sanksi.

Peran serta upaya pemerintah dalam rangka pengembalian hak atas tanah masyarakat Long Midang, sesuai dengan undang-undang nomor 56 PRP tahun 1960 tentang penetapan luas tanah pertanian sudah maksimal dengan cara, sosialisasi, pelaksanaan program pengembalian hak atas tanah pertanian masyarakat Long Midang yang memiliki tanah melebihi ketentuan, dan 
kerjasama perangkat desa di Long Midang dengan pemerintah.

Adapun saran dalam penelitian ini seharusnya Pemerintah dalam hal ini, seharusnya memberikan perhatian lebih dan berkala kepada masyarakat yang ada di daerah perbatasan khususnya dalam hal membantu proses pengembalian batas hak atas tanah pertanian masyarakat yang memiliki tanah pertanian melebihi ketentuan yang berlaku. Sehingga terhadap tanah pertanian masyarakat yang ada dapat dimiliki sesuai dengan ketentuan yang berlaku dan memiliki kepastian hukum.

Dan masyarakat yang memiliki tanah pertanian melebihi batas seharusnya menguasai tanah pertanian sesuai dengan ketentuan yang berlaku, agar terhadap tanah pertanian yang di kuasai memiliki kepastian hukum yang jelas, sehingga tidak terjadinya sengketa terhadap tanah-tanah pertanian yang dimiliki masyarakat, serta membantu program pemerintah dalam terciptanya tertib pertanahan di Indonesia dalam hal bidang pertanian.

\section{DAFTAR PUSTAKA}

\section{BUKU :}

Abdul Muhammad, 2004, Hukum Dan Penelitian Hukum, Penerbit Citra Aditya Bakti, Bandung.

A.P. Parlindungan, 2009, Pendaftaran Tanah Di Indonesia, Mandar Maju, Bandung.

Adrian sutedi, 2009, Peralihan Hak Atas Tanah Dan Pendaftarannya, Sinar Grafika, Jakarta.

A.P.Parlindungan, 1999 , Pendaftaran Tanah Di Indonesia, Mandar Maju Bandung.

Boedi Harsono, 2007, Мепији Penyempurnaan HukuMTanah Nasional, Universitas Trisakti, Jakarta.
Florianus SP Sangun, 2007, Tata Cara Mengurus Sertifikat Tanah, Visimedia, Jakarta.

Ismaya,Samun. 2011, Pengantar Hukum Agraria, Penerbit Graha Ilmu, Yogyakarta.

Jimmy Joses Sembiring, 2010, Panduan Mengurus Sertifikat Tanah, Penerbit Visimedia, Jakarta.

Ny.Arie Sukanti Hutagalung Dan Markus Gunawan, 2008, Kewenangan Pemerintah Dibidang Pertanahan, Rajawali Pers, Jakarta.

R.Soerapto, 1976, Undang-Undang Agraria Dalam Praktek, Mitra Sari, Jakarta. 
Suratman dan H.Philip Dillah, 2013, Metode Penelitian Hukum, Alfabeta, Bandung.

Sugiyono, 2013, Metode Penelitian Kuantitatif, Kualitatif Dan R\&D, Penerbit Alfabeta, vol.19, Bandung.

Supriadi, 2007, Hukum Agraria, Penerbit Sinar Grafika, Jakarta.

Urip Santoso. 2005, Hukum Agraria Dan Hak-hak Atas Tanah, Penerbit Prenada Media Group, Jakarta.

, 2010, Pendaftaran

Dan Peralihan Hak Atas Tanah, Kencana, Jakarta.

\section{Perundang-undangan :}

Undang-Undang Dasar 1945 Amandemen ke IV (empat).

Undang-Undang Pokok Agraria Nomor 5 Tahun 1960 Tentang Peraturan Dasar Pokok-pokok Agraria.

Undang-Undang Nomor 56 Peraturan Pemerintah Pengganti UndangUndang Tahun 1960 Tentang Penetapan Luas Tanah Pertanian.

Peraturan Pemerintah Nomor 24 Tahun 1997 Tentang Pendaftaran Tanah.

Peraturan Menteri Negara Agraria Nomor 3 Tahun 1997 Tentang Ketentuan Pelaksanaan Peraturan Pemerintah Nomor 24 Tahun 1997 Tentang Pendaftaran Tanah.

\section{Media Internet :}

www.google//http:hukumpertanahandiIndo nesia.// diakses tanggal, 08.08.2017, jam 22.23 WITA.

www.google//http:elkafilah.wordpress.com //kepemilikan_hak hak_atas_tanah_dan aplikasinya// diakses tanggal 09.08.2017, jam 16.47 WITA.

www.google//http:www.lepank.com,_peng ertian_tujuan_menurut_beberapa_ahli/ diakses tanggal 11.08.2017, Jam, 01.23 WITA. 